\title{
INTERACTIVE E-MATERI BASED ON DESKTOP FOR LINEAR ALGEBRA COURSE
}

\author{
Saiful Khair ${ }^{1}$, Trienani Hariyanti ${ }^{2}$ \\ Computer Science Department, Sumbawa University of Technology \\ Jl. Raya Olat Maras Batu Alang, Sumbawa 84371, Indonesia \\ Email: saifulkhair@uts.ac.id
}

Keywords:

E-materi

Linear Algebra

Multimedia Development Life Cycle

\begin{abstract}
Interactive e-materi based on desktop for linear algebra course is a structured application consists of chapter summaries, exercises, simulations and tutorial video for students that take the course in the third semester at computer science department. The purpose of this research is a new learning media that has a high level of accuracy and systematic to increase student's understanding of the material provided by the lecturer. The application was built using Multimedia Development Life Cycle (MDLC) research design consisting of 6 steps: concept, design, collecting material, assembly, testing, and distribution. Aside from being an alternative to students who have difficulty to an in-depth understanding of the course, the lecturer can use this application to upgrade student's activity in their lecture with exercises and simulations in this application.
\end{abstract}

\section{Introduction}

The development of Information and Communication Technology (ICT) has progressed so rapidly and can bring changes in every field of human life, especially in education. Improving the quality of education through ICT is expected to be one solution in upholding one of the pillars of education. The Ministry of Education and Culture is very serious about putting the pillars of education through its mission known as $5 \mathrm{~K}$ namely Availability (Ketersediaan), Affordability (Keterjangkauan), Quality and Relevance (Kualitas dan Relevansi), Equality (Kesetaraan) and Certainty (Kepastian). Learning resources are one aspect of education that must be available, affordable, qualified, relevant to the needs of the world of social life, and accessible to all, regardless of gender, age, religion, race, and guaranteed certainty in its accession. One source of learning that corresponds to the definition that utilizes ICT is e-materi [1]. E-materi is a set of information in electronic form that presents a particular field of science for learning purposes. E-materi can be an alternative media to help the learning process related to a field of knowledge without knowing space and time. The presentation of e-materi consisting of material, audio, video, simulation, assessment and evaluation process is expected to change the paradigm of learning strategy that has been centered only on educators (lecturer) to be learner-centered (student).

Linear algebra is a third semester's course of computer science department in Universitas Teknologi Sumbawa. This course has a relatively high degree of difficulty for students with low understanding background on the matrix and vector algebra. Making interactive e-materi based on desktop for this course is expected to improve the quality of learning, the quality of teaching materials, the quality of learning activities, and the independence of students in linear algebra courses. Also, it can build interaction between lecturers with students, between students, and students with various related learning resources.

\section{Research Methodology}

E-materi application used Multimedia Development Life Cycle (MDLC) research design that comes from Luther [2] consists of 6 steps, i.e.: 


\section{A. Concept}

The concept step aims to formulate the objectives of this application, user, and the description of the material as well as what features are provided in the e-materi.

\section{B. Design}

In this step, we present the detail specification about application's architecture, simulation, interface, style, and material needed for the application. This step consists of some design, i.e., storyboard, system design, structured hierarchy menu and State Transition Diagram.

\section{Material Collecting}

Material collecting is the collection step of materials that suit the needs of the application [3]. These materials include material from each chapter taken by linear algebra books in [4] and [5], video tutorials and simulations tailored to the needs.

\section{Assembly}

The assembly step is the stage of making the entire material that has been collected. E-materi create based on the design step, such as storyboard to interface design using any programming language and design's software to create a display design or image editing.

\section{E. Testing}

After the e-materi creation phase is completed, the next step is to test whether there is any error or not on the functionality aspect of each e-materi's unit. Testing is also done to see if the application has met the criteria that are by the design goals or not. This step includes alpha testing and black box testing.

\section{F. Distribution}

This stage is the last stage where e-materi is stored in a storage medium. At this stage also evaluated the applications that have been made to be better than before.

\section{Result and Discussion}

Based on the research design of Multimedia Development Life Cycle (MDLC), the process to create interactive e-materi based on desktop for linear algebra course are:

\section{A. Concept}

In determining the concept of e-materi, a literary study of materials related to matrix algebra, linear equations system, determinants and matrix inverse and similar studies as a reference in presenting the material to be presented. Table 1 presents a concept description of e-materi application.

Table 1. The description of e-materi

\begin{tabular}{|c|c|}
\hline Item & Description \\
\hline Title & Interactive e-materi based on desktop for linear algebra course \\
\hline Goal & $\begin{array}{l}\text { Increase the understanding of students computer science on linear algebra } \\
\text { course }\end{array}$ \\
\hline User & Student of computer science department that takes linear algebra course \\
\hline Features & $\begin{array}{l}\text { Document presentations, exercises and simulation calculations as well as } \\
\text { video tutorials related to matrix algebra, systems of linear equations, } \\
\text { determinants, and the inverse of a matrix. }\end{array}$ \\
\hline $\begin{array}{l}\text { Interaction } \\
\text { with user }\end{array}$ & Exercises and simulation need the user to start and input the number. \\
\hline
\end{tabular}

\section{B. Design}

In this step, the specification of e-materi present the storyboard, system design, and hierarchy structured menu. 


\section{Storyboard Design}

Tabel 2 provided storyboard that present visualization of idea from e-materi application.

Table 2. Design of storyboard

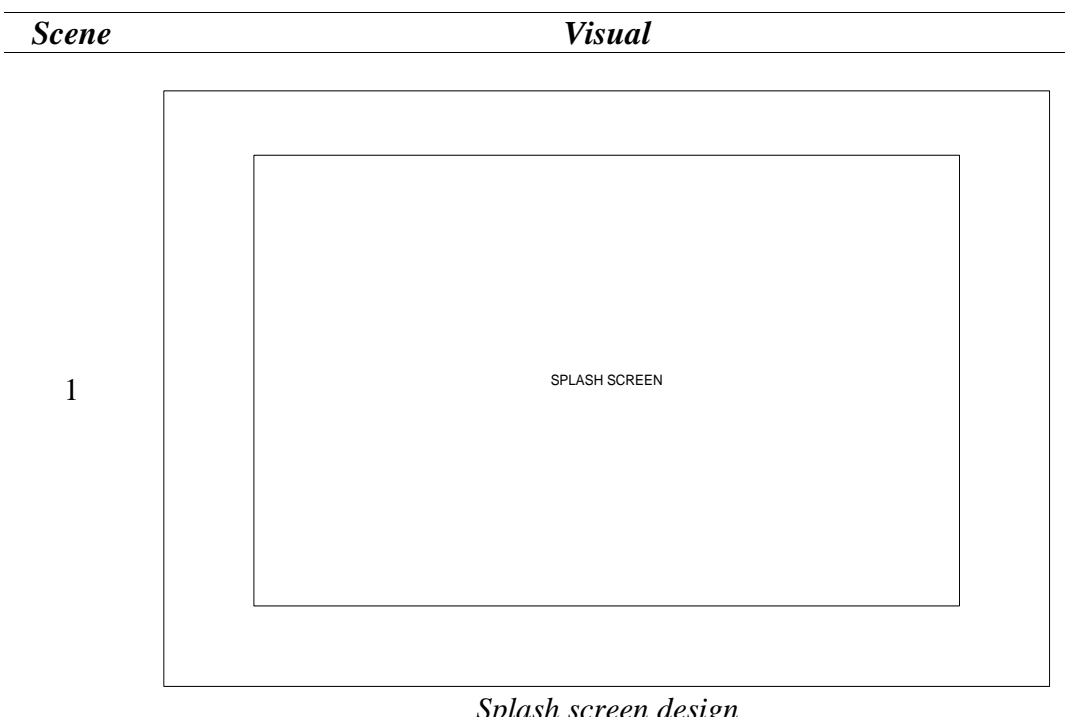

Splash screen design

2

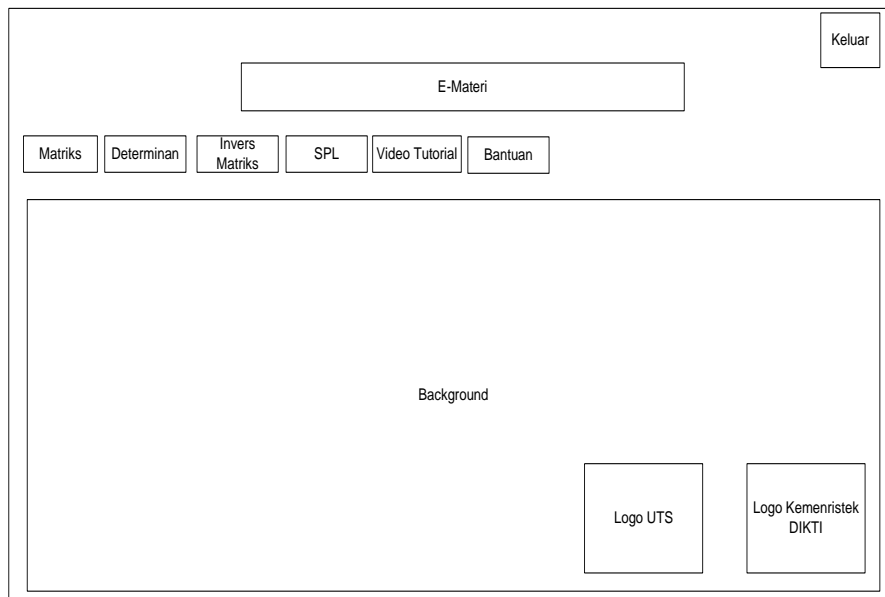

Main menu form design consists of six buttons, i.e., Matriks,

Determinan, Invers Matriks, Sistem Persamaan Linear, Video Tutorial dan Bantuan. In the right corner side, there are university and Kementerian Riset dan Teknologi logos.

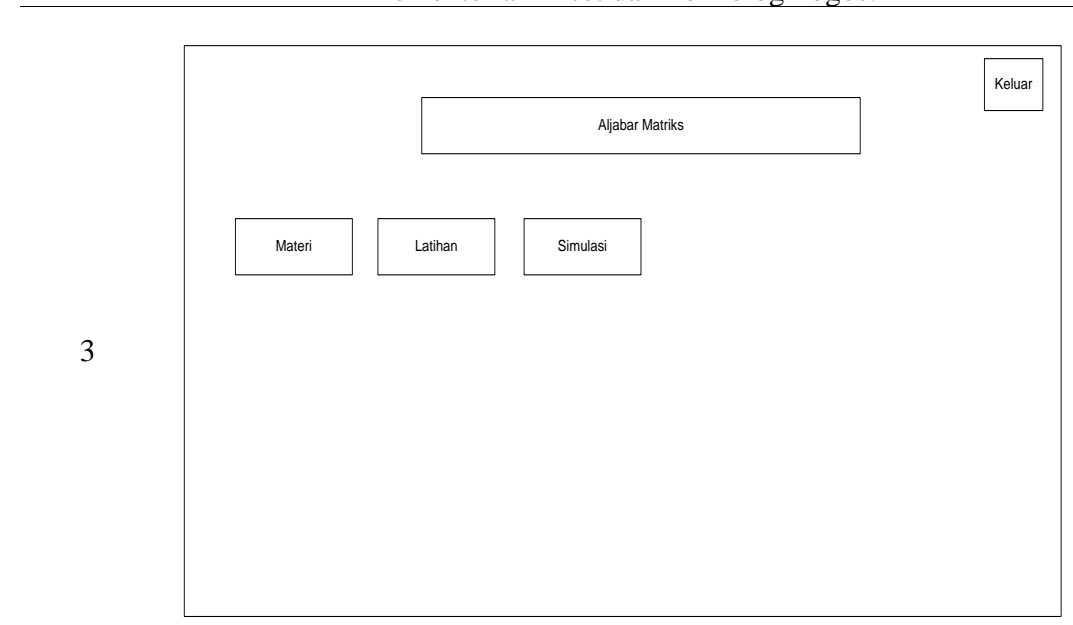

Matrix algebra form design where three buttons were provided, i.e., Materi, Latihan, and Simulation 


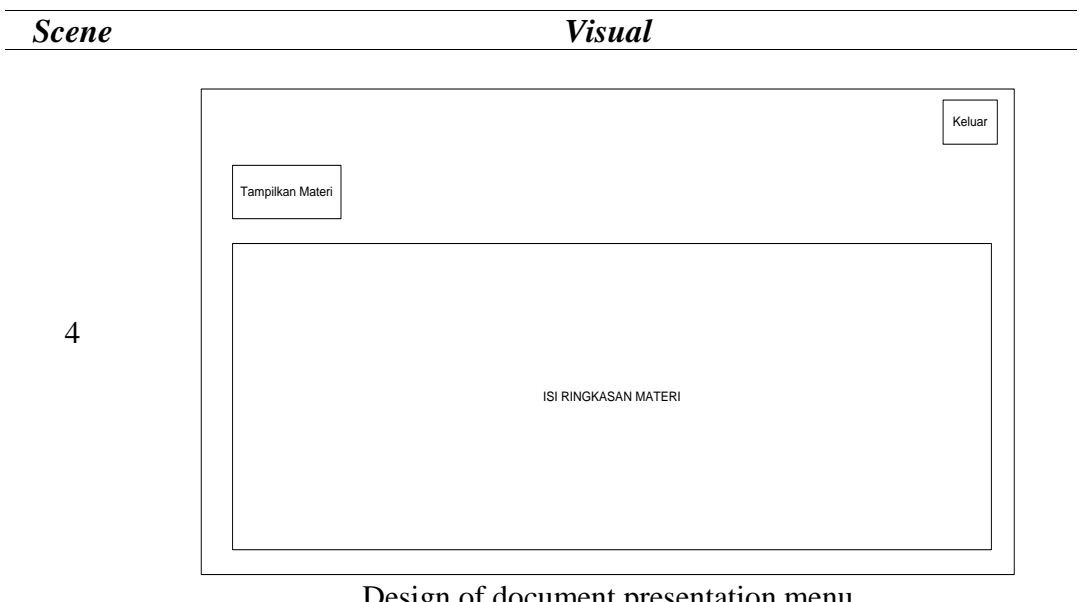

Design of document presentation menu

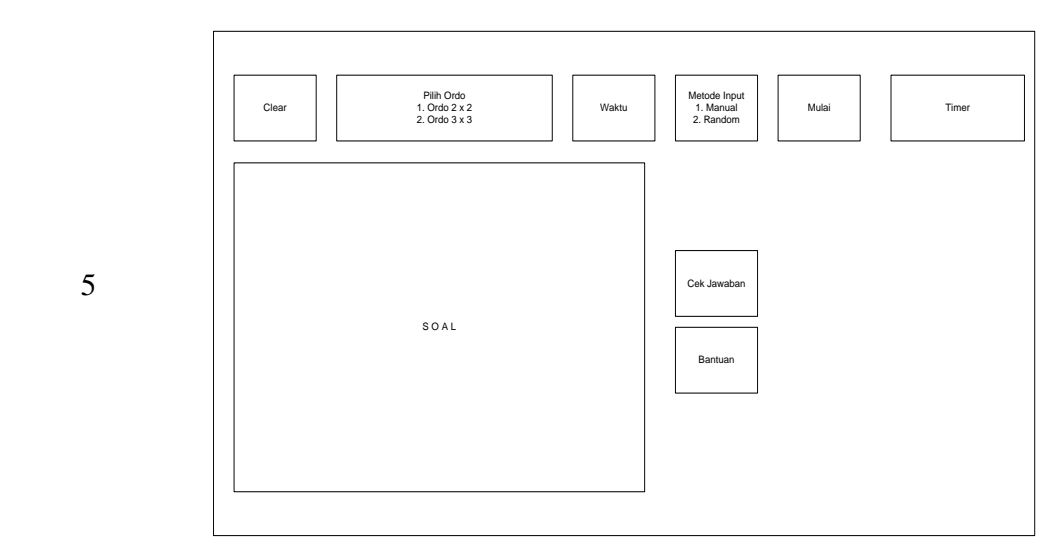

Design of calculation exercise menu

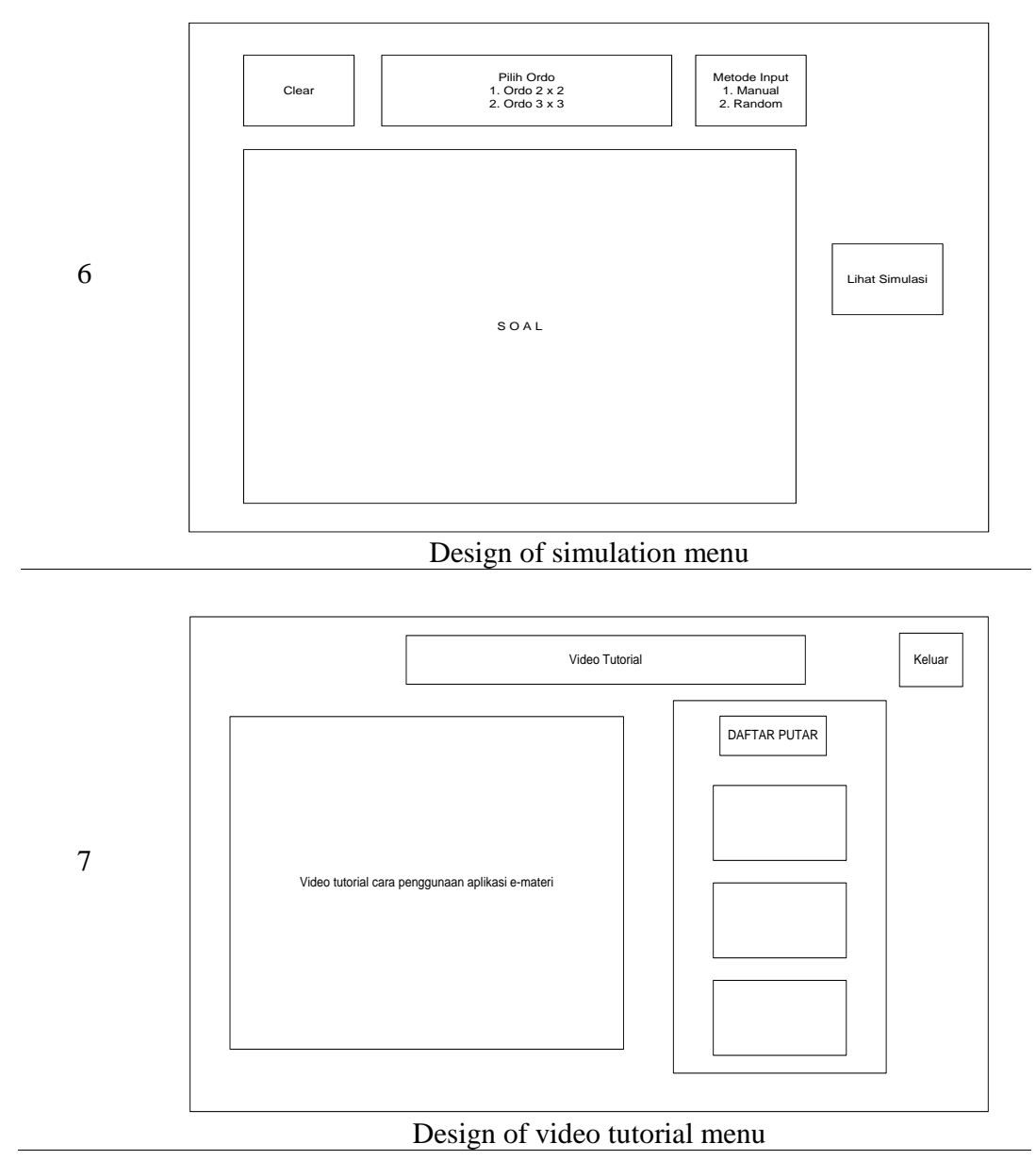

Saiful Khair (Interactive E-materi Based on Desktop for Linear Algebra Course) 


\section{System Design}

This step consists of:

a. Input Design

E-materi only accepts integer input in exercise and simulation.

b. Process Design

For process design, e-materi works based on given input and does not cause errors in calculations. Some of the processes included in the e-materi include addition, subtraction, multiplication of matrices, Elementary Row Operations, Gauss Jordan Elimination, matrix invers, exercise and simulation calculations relating to those materials.

\section{c. Output Design}

In general, the output design of this application is the user can know several steps of each calculation in detail. The output form is the elements that have been processed along with the steps how to calculate it through the formulas obtained from the literature study.

3. Hierarchy Structure Menu Design

Figure 1 shows the design of hierarchy structure menu to simplify the process design.

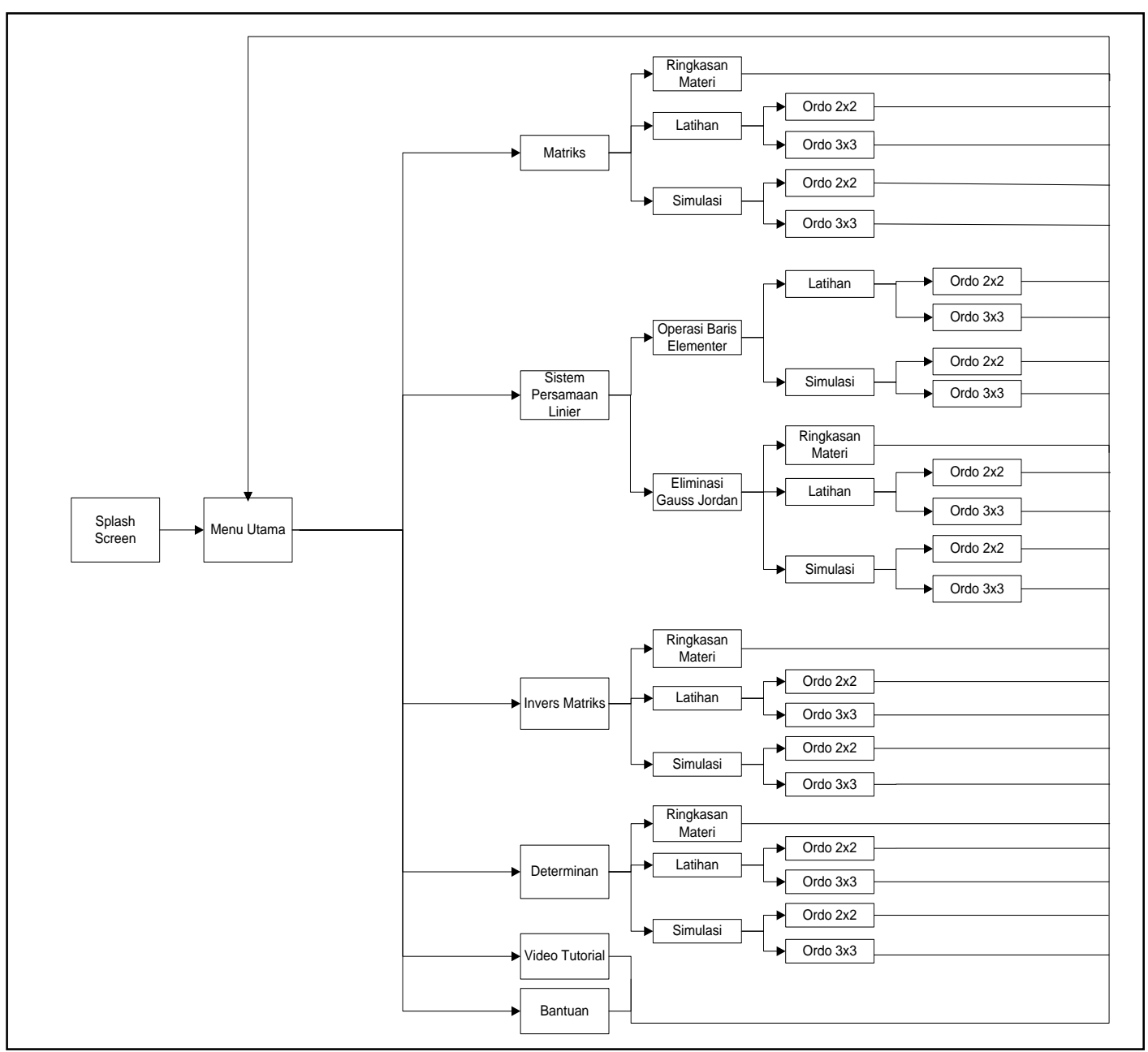

Figure 1. Hierarchy structure menu of e-materi 


\section{Material Collecting}

The materials required for building e-materi are presentations related to matrix algebra, determinants, inverse matrices and systems of linear equations including videos related to those materials taken from youtube. Photoshop CS3 used to create the splash screen and cover design.

\section{Assembly}

This step shows the result of building the application with Visual Basic 2010 express. The present menu customized with the previous design step.

1. View of splash screen

Figure 2 shows splash screen that made with design software Photoshop CS3.

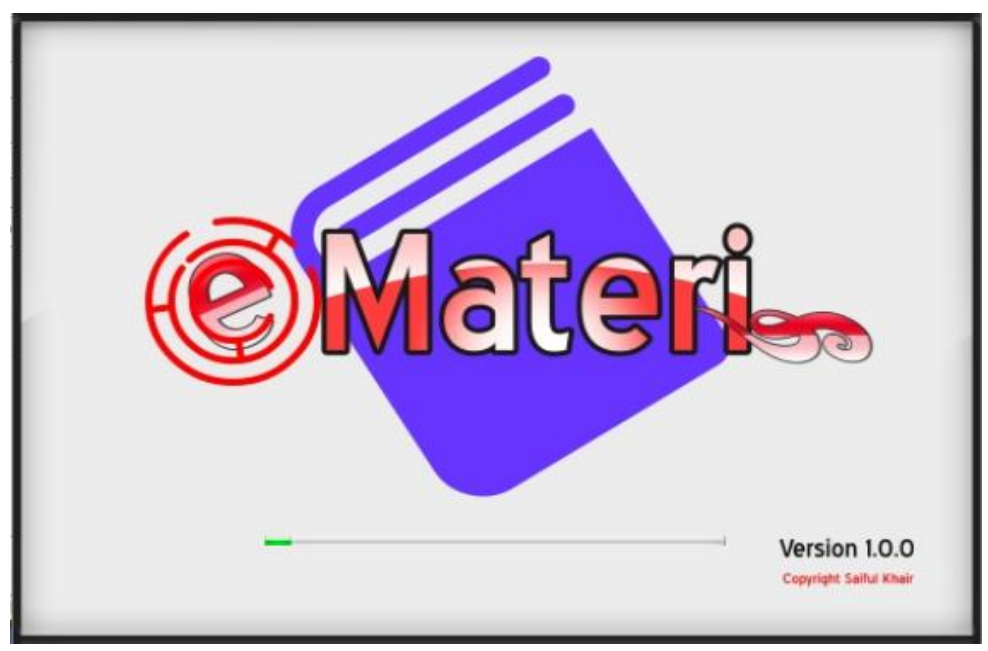

Figure 2. Splash screen of e-materi

2. View of Main Menu

In the main menu, the menus are displayed according to the design of the researcher, i.e., matrix, determinant, inverse matrix, video tutorial, about and help with the background designed with the logo of the university and logo RISTEK DIKTI (Figure 3).

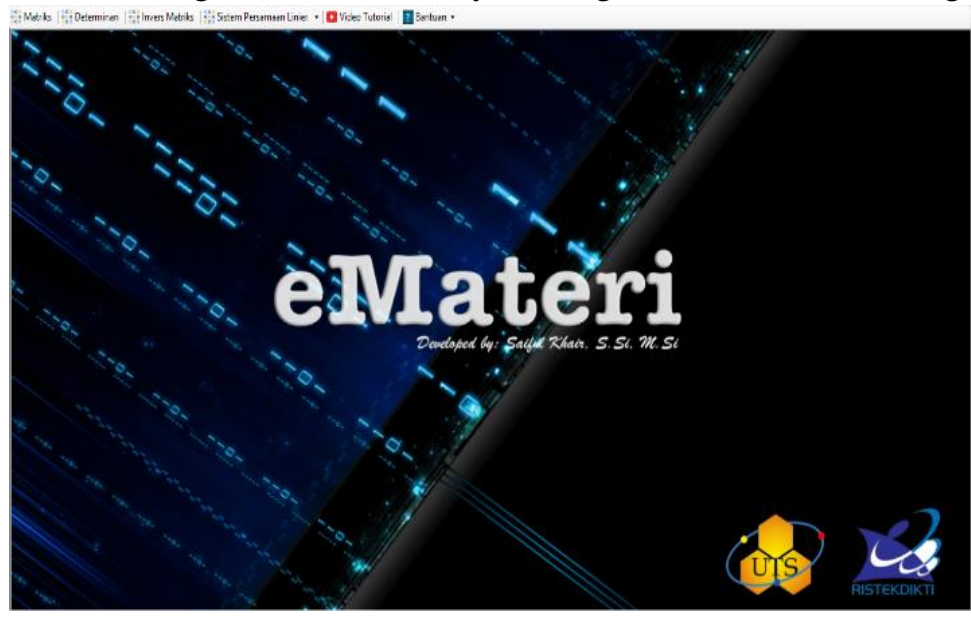

Figure 3. View of main menu

3. View of summary menu

In the material display menu, a summary of the material related to all the chapters in the course is displayed using the portable data format (pdf) extension. The material was first made using latex then immersed in the e-materi (figure 4). 


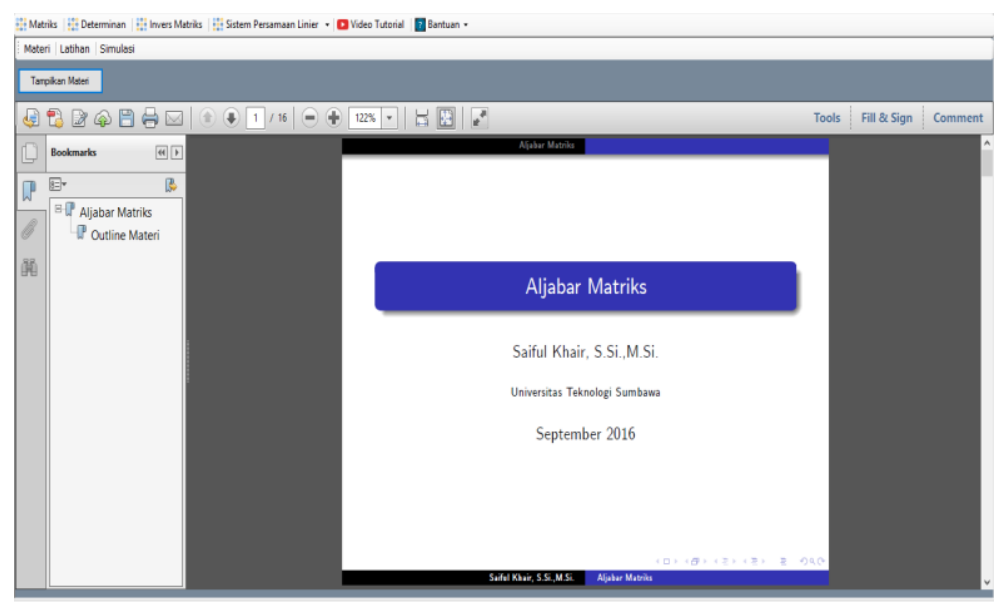

Figure 4 . View of summary menu

4. View of exercise menu

Figure 5 is an interface of the $3 \times 3$ order matrix summing exercise. In this form, the user can try his ability to calculate quickly by using the time provided beforehand to add/ subtract/multiply matrix.

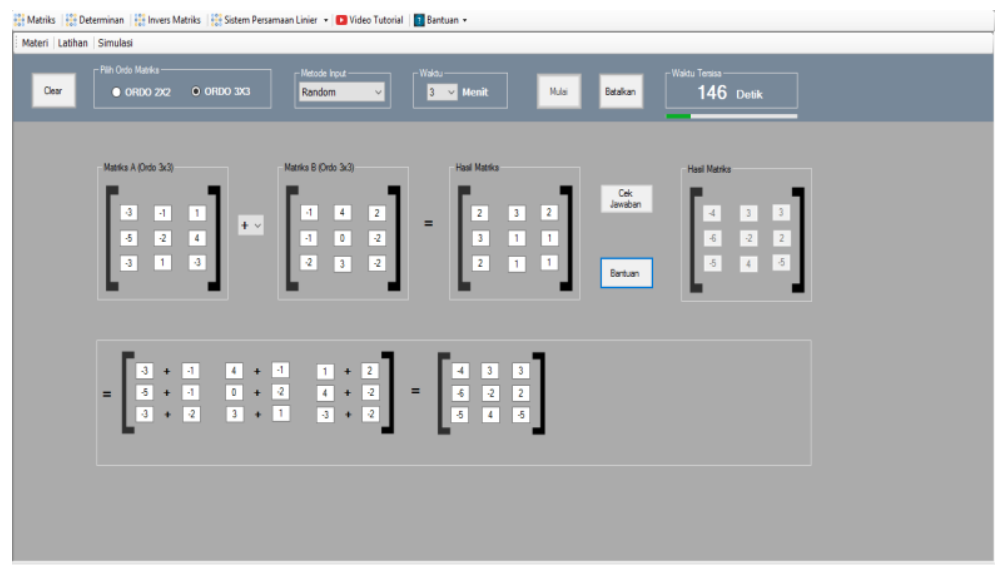

Figure 5. View of exercise menu

5. View of simulation menu

Figure 6 shows a matrix multiplication simulation menu with a $3 \times 3$ order with random input. Users can choose matrix order and input in random or manual. To see the working steps, we provided simulation view button on the top right.

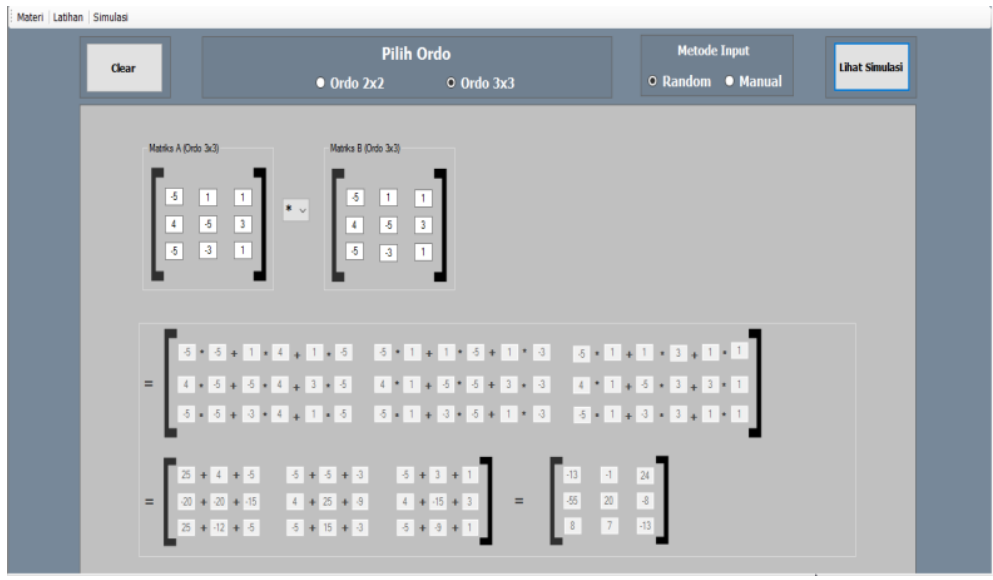

Figure 6. View of simulation menu 
6. View of tutorial video menu

In the video tutorial menu, there is a playlist of tutorial videos on the right that can be selected as desired. The videos provided are taken from the youtube website for materials related to e-materi (figure 6).

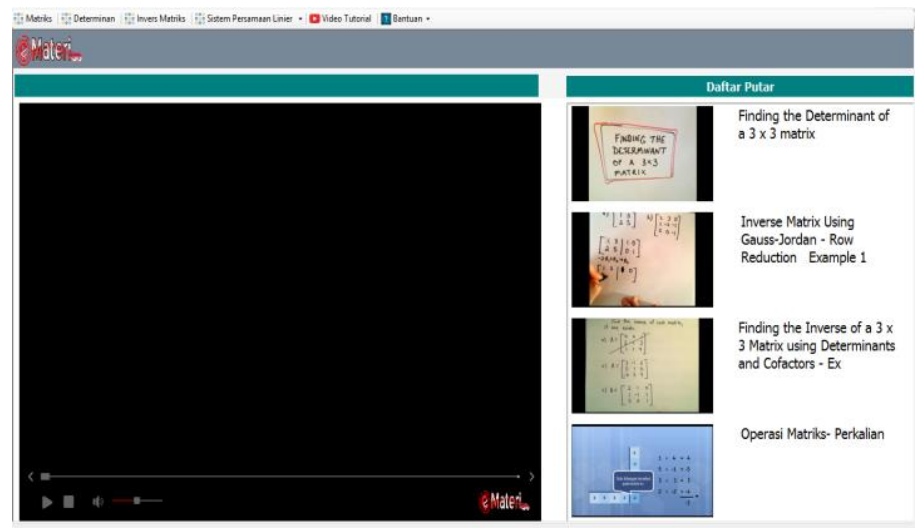

Figure 7. View of tutorial video menu

7. View of matrix determinant

Figure 8 below shows a menu of matrix determinant exercises that are inputted randomly and the user gives the wrong answer. When the answer is incorrect, the program will display a dialog box message that notifies the wrong answer to the user.

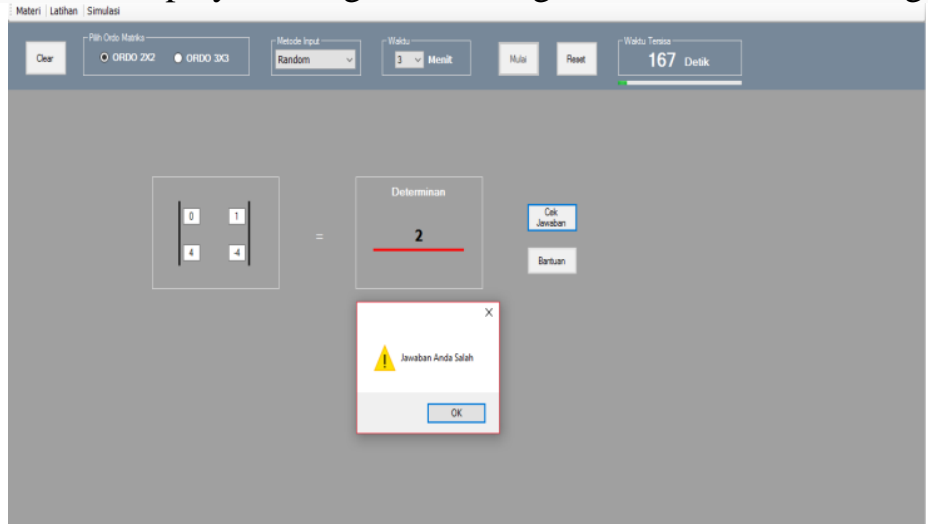

Figure 8. View of matrix determinant

8. View of matrix inverse exercise

E-materi allows users to perform inverse matrix calculations. Figure 8 presents the inverse matrix inverse calculation.

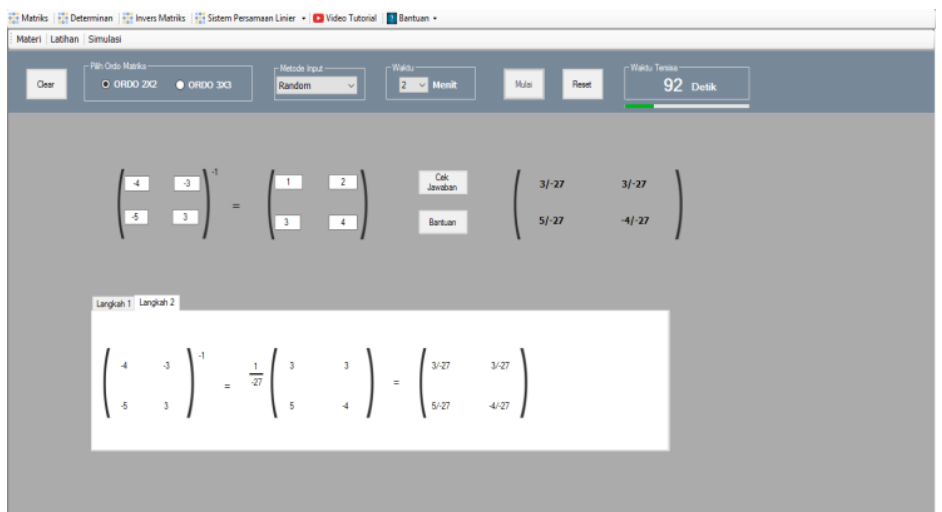

Figure 9. View of matrix inverse exercise 
9. View of help menu

The help view is for users who are not familiar with e-materi. Figure 10 presents the general help for e-materi.

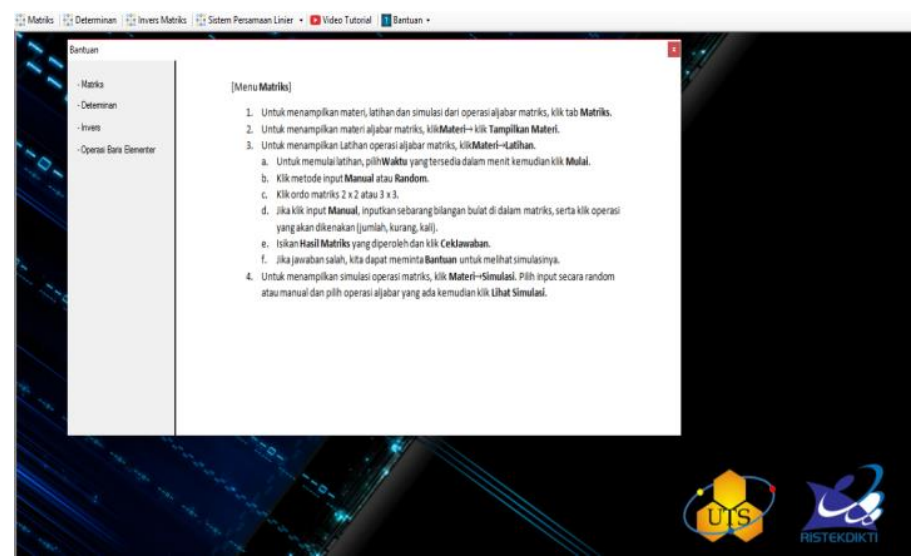

Figure 10. View of help menu

\section{E. Testing and Evaluation}

This step is the testing phase of e-materi based on alpha testing and black box testing, where testing is done by colleagues and the scope of testing based on input and output. The black box testing results are presented in the following set of Table 3.

Table 3. Black box testing of e-materi

\begin{tabular}{|c|c|c|c|}
\hline \multicolumn{4}{|c|}{ Cases and Test Results (Normal Data) } \\
\hline Data Input & Expected Result & Observation & Conclusion \\
\hline $\begin{array}{l}\text { Gives any arbitrary integer } \\
\text { input on the empty label } \\
\text { provided as a } \\
\text { representation of the } \\
\text { matrix form }\end{array}$ & $\begin{array}{l}\text { Displays the result of } \\
\text { addition, subtraction, } \\
\text { multiplication, } \\
\text { determinant, matrix } \\
\text { inverse. }\end{array}$ & $\begin{array}{l}\text { Displays the sum result, } \\
\text { subtraction and } \\
\text { multiplication of the } \\
\text { matrix with the correct } \\
\text { answer }\end{array}$ & Accepted \\
\hline $\begin{array}{l}\text { Provides input answers in } \\
\text { the form of integers which } \\
\text { is the correct answer in the } \\
\text { exercise and simulation }\end{array}$ & $\begin{array}{l}\text { Displays the sum, } \\
\text { decrement, determinant, } \\
\text { inverse, line operation and } \\
\text { gauss Jordan elimination }\end{array}$ & $\begin{array}{l}\text { Displays the result of } \\
\text { addition, subtraction, } \\
\text { determinant, inverse, } \\
\text { line operation and } \\
\text { elimination of gauss } \\
\text { Jordan with correct } \\
\text { value }\end{array}$ & Accepted \\
\hline $\begin{array}{l}\text { Provide input answers in } \\
\text { the form of numbers which } \\
\text { is the wrong answer in the } \\
\text { exercise and simulation }\end{array}$ & $\begin{array}{l}\text { Display message } \\
\text { "jawaban anda salah" }\end{array}$ & $\begin{array}{l}\text { Display message } \\
\text { "jawaban anda salah" }\end{array}$ & Accepted \\
\hline \multicolumn{4}{|c|}{ Cases and Test Results (Unnormal Data) } \\
\hline Data Input & Expected Result & Observation & Conclusion \\
\hline Do not enter numbers & $\begin{array}{l}\text { Display message } \\
\text { "Lengkapi Jawaban" }\end{array}$ & $\begin{array}{l}\text { Display message } \\
\text { "Lengkapi Jawaban" }\end{array}$ & Accepted \\
\hline $\begin{array}{l}\text { Input is a letter or a non- } \\
\text { numeric character }\end{array}$ & Can not display anything & $\begin{array}{l}\text { Can not display } \\
\text { anything }\end{array}$ & Accepted \\
\hline
\end{tabular}

\section{Conclusion}

Interactive e-materi based on desktop applications for linear algebra course has been successfully built. We used Multimedia Development Life Cycle (MDLC) research design that contains some multimedia elements, i.e., text, audio, and video located on the material summary, exercises, simulations and tutorial videos to develop this e-materi. This E-materi focuses on matrix algebra, determinant, inverse matrices, and some material on Linear Equation Systems. For further research, other materials can be incorporated and make some improvements to the exercises and simulations present in the e-materi as well as the implementation in the lecture room. 


\section{Acknowledgment}

This research is supported by "Penelitian Dosen Pemula Tahun 2016 program" from the Ministry of Research and Technology Directorate of Higher Education (KEMERISTEK DIKTI), Republic of Indonesia.

\section{References}

[1] Direktorat Pembelajaran dan Kemahasiswaan DIKTI, Pedoman Pengembangan e-Materi. Jakarta: Direktorat Jendral Pendidikan Tinggi, 2012.

[2] A. C. Luther, Authoring interactive multimedia. Academic Press Professional, Inc., 1994.

[3] S. Nurajizah, "Implementasi Multimedia Development Life Cycle pada Aplikasi Pengenalan Lagu Anak-Anak Berbasis Multimedia," PROSISKO: Jurnal Pengembangan Riset dan Observasi Sistem Komputer, vol. 3, no. 2, 2016.

[4] S. J. Leon, Aljabar Linear dan Aplikasinya. Jakarta: Erlangga, 2001.

[5] A. Arifin, Aljabar Linear, 2 ed. Bandung: Institut Teknologi Bandung, 2000. 